\title{
Life cycle assessment of cheese and whey production in the USA
}

\author{
Daesoo Kim • Greg Thoma • Darin Nutter • \\ Franco Milani • Rick Ulrich • Greg Norris
}

Received: 30 July 2012 / Accepted: 29 January 2013 /Published online: 19 February 2013

(C) The Author(s) 2013. This article is published with open access at Springerlink.com

\begin{abstract}
Purpose A life cycle assessment was conducted to determine a baseline for environmental impacts of cheddar and mozzarella cheese consumption. Product loss/waste, as well as consumer transport and storage, is included. The study scope was from cradle-to-grave with particular emphasis on unit operations under the control of typical cheese-processing plants. Methods SimaPro@ 7.3 (PRé Consultants, The Netherlands, 2013) was used as the primary modeling software. The ecoinvent life cycle inventory database was used for background unit processes (Frischknecht and Rebitzer, J Cleaner Prod 13(13-14):1337-1343, 2005), modified to incorporate US electricity (EarthShift 2012). Operational data was collected from 17 cheese-manufacturing plants representing $24 \%$ of mozzarella production and $38 \%$ of cheddar production in the USA. Incoming raw milk, cream, or dry milk solids were allocated to coproducts by mass of milk solids. Plant-level engineering assessments of allocation fractions were adopted for major inputs such as electricity, natural
\end{abstract}

Responsible editor: Niels Jungbluth

Electronic supplementary material The online version of this article (doi:10.1007/s11367-013-0553-9) contains supplementary material, which is available to authorized users.

D. Kim $\cdot$ G. Thoma $(\triangle) \cdot$ R. Ulrich

Ralph E. Martin Department of Chemical Engineering, University of Arkansas, Fayetteville, AR 72701, USA

e-mail: gthoma@uark.edu

D. Nutter

Department of Mechanical Engineering, University of Arkansas, Fayetteville, AR 72701, USA

\section{G. Norris}

Center for Health and the Global Environment, Harvard School of Public Health, Harvard University, Boston, MA 02115, USA

F. Milani

Jeneil Biotech, Inc., 400 N. Dekora Woods Blvd.,

Saukville, WI 53080, USA gas, and chemicals. Revenue-based allocation was applied for the remaining in-plant processes.

Results and discussion Greenhouse gas (GHG) emissions are of significant interest. For cheddar, as sold at retail ( $63.2 \%$ milk solids), the carbon footprint using the IPCC 2007 factors is $8.60 \mathrm{~kg} \mathrm{CO}_{2} \mathrm{e} / \mathrm{kg}$ cheese consumed with a $95 \%$ confidence interval (CI) of 5.86-12.2 $\mathrm{kg} \mathrm{CO}_{2} \mathrm{e} / \mathrm{kg}$. For mozzarella, as sold at retail (51.4 \% milk solids), the carbon footprint is $7.28 \mathrm{~kg} \mathrm{CO}_{2} \mathrm{e} / \mathrm{kg}$ mozzarella consumed, with a $95 \% \mathrm{CI}$ of $5.13-9.89 \mathrm{~kg} \mathrm{CO}_{2} \mathrm{e} / \mathrm{kg}$. Normalization of the results based on the IMPACT $2002+$ life cycle impact assessment (LCIA) framework suggests that nutrient emissions from both the farm and manufacturing facility wastewater treatment represent the most significant relative impacts across multiple environmental midpoint indicators. Raw milk is the major contributor to most impact categories; thus, efforts to reduce milk/cheese loss across the supply chain are important.

Conclusions On-farm mitigation efforts around enteric methane, manure management, phosphorus and nitrogen runoff, and pesticides used on crops and livestock can also significantly reduce impacts. Water-related impacts such as depletion and eutrophication can be considered resource management issues - specifically of water quantity and nutrients. Thus, all opportunities for water conservation should be evaluated, and cheese manufacturers, while not having direct control over crop irrigation, the largest water consumption activity, can investigate the water use efficiency of the milk they procure. The regionalized normalization, based on annual US per capita cheese consumption, showed that eutrophication represents the largest relative impact driven by phosphorus runoff from agricultural fields and emissions associated with whey-processing wastewater. Therefore, incorporating best practices around phosphorous and nitrogen management could yield improvements.

Keywords Cheese · Greenhouse gas (GHG) emissions · Life cycle assessment (LCA) - Supply chain 


\section{Introduction}

Consumers are increasingly aware of the sustainability characteristics of the products they purchase. As a result, a key issue for the dairy industry is ensuring that dairy manufacturing, especially cheese in this study, is conducted with sustainability in mind. At the same time, major brands and retailers are adding environmental reporting requirements for their suppliers. Therefore, actors across the US dairy industry are working together to improve environmental performance for the entire supply chain and towards that end commissioned this study.

Life cycle assessment (LCA) is a technique for assessing the potential environmental impacts associated with a product, process, or service throughout its lifetime. LCAs have been used as a tool to identify "hot spots" in the production chain that may introduce opportunities for simultaneously lowering environmental impacts and improving efficiency and profitability (Eide 2002). This study is a cradle-to-grave LCA of natural cheese production focused on quantifying cumulative energy demand; emissions to air, water, and land; and consumption of water and other natural resources. There is a need to assess the impacts of these inventory flows on climate change, resource depletion, and human and ecosystem health.

Cheddar and mozzarella were chosen on the basis that they represent about $64 \%$ (by mass) and $80 \%$ (by sales) of all cheese produced in the USA (IDFA 2010). The principal objective of this work is to determine a baseline for the environmental impacts associated with production and consumption of cheddar and mozzarella cheese and associated whey products in the USA.

\subsection{Literature review and background}

Previous LCAs for dairy products have focused primarily on agricultural production (Cederberg and Mattsson 2000; Haas et al. 2001; Gerber et al. 2010). LCAs for the cheese industry are not extensive, but important research has been conducted in Australia (Lundie et al. 2003), Scandinavia (Berlin 2002; Dalgaard and Halberg 2004), and Western European countries (Bianconi et al. 1998; Hospido et al. 2003; Williams et al. 2006). In addition, considerable research has been done on food packaging, with some emphasis on milk packaging in particular (Keoleian and Spitzley 1999); however, no information regarding cheese packaging has been identified. Research on the life cycle of dairy products from retail to consumer to end-of-life has been minimal.

Many of the existing studies consider the footprint of milk leaving the farm; our review of the literature revealed few postfarm analyses. Sonesson and Berlin (2003) suggest that both packaging and transportation from the retail outlet to the home are major contributors. Other work by this group highlights the need for improvements in process management to minimize milk waste during processing of different products (Berlin
2005; Berlin et al. 2007). Nielsen and Høier (2009) have investigated yield improvement effects on environmental impacts of cheese production. In terms of overall global warming potential (GWP) of the supply chain, the majority of the effect originates from the farming activity, primarily from methane emissions from the cows and fertilizer production and use for feed. Another case study on Dutch cheese reached similar conclusions (van Middelaar et al. 2011). One recent study of US cheese production by Capper and Cady (2012) estimated the greenhouse gas (GHG) emissions from production of 500,000 tons of cheddar cheese derived from Jersey and Holstein milk, both with and without recombinant bovine somatotropin use. They report that cheddar cheese produced from Jersey milk had a lower footprint than cheese produced from Holsteins and use of recombinant bovine somatotropin further reduced GHG.

Several cradle-to-grave LCAs have been conducted for dairy products, including those previously noted. However, the scale, scope, and location were different from this study, and thus, they have limited direct applicability for assessing the US situation.

\section{Methods}

This study has been structured following ISO 14040-compliant and ISO 14044-compliant LCA methodology (ISO 2006a, b). These standards provide an internationally agreed method of conducting LCA, but leave significant degrees of flexibility in methodology to customize individual projects.

\subsection{Goal and scope of the study}

The main goal of this work was to equip US cheese industry stakeholders with timely, defensible, and relevant information to support the incorporation of environmental performance into decision-making and support the development of innovative products, processes, and services. The study will provide cheese manufacturers an opportunity to benchmark their individual performance against a 2009 industry average, which is reported in this paper.

The scope of the project was a cradle-to-grave assessment with particular emphasis on the unit operations under direct control of a typical cheese-processing plant. In particular, these unit operations were transport of raw milk to the plant, cheese and whey manufacture, and delivery of cheese and whey products to the first customer.

\subsection{Functional unit}

Because cheese is produced with variable moisture content, the results are presented on a moisture-free basis. Three relevant functional units were defined: 
One ton $(1,000 \mathrm{~kg})$ of cheddar cheese consumed (dry weight basis);

One ton of mozzarella cheese consumed (dry weight basis);

One ton of dry whey delivered (dry weight basis).

\subsection{System boundaries and cutoff criteria}

System boundaries encompass production of raw milk (feed production and on-farm), cheese manufacturing, packaging, transport, retail, consumption, and end-of-life (Fig. 1). We also analyzed the gate-to-grave system to increase resolution of the manufacturing and use phases. The boundary for whey does not include retail or consumption due to lack of data. We did not include in the inventory processes activities such as employee commuting; air travel; and veterinary, accounting, or legal services.

In determining whether to expend project resources to collect data for the inclusion of specific inputs, a $1 \%$ cutoff threshold for mass and energy was adopted. Although the study is intended to be comprehensive in consideration of impacts resulting from cheese supply chains, it is not a detailed engineering analysis of specific unit operations within the manufacturing sector. Thus, for example, we did not assign a specific energy requirement for cheese-making vats, cleaning in place, or starter culture operations, rather, we used the information available at the manufacturing plant scale, coupled with allocation of burdens to multiple plant products, to define the burden assigned to cheese, whey, and other coproducts. For this reason, it is important to state that all operations, as well as facility overhead (computers, heating, lights, etc.), are accounted for in this work.

\subsection{Allocation}

Milk is the most significant input in the manufacturing of cheese, and milk solids (4.9\% lactose, $3.4 \%$ fat, $3.3 \%$ protein, and $0.7 \%$ minerals) represent the important fraction of raw milk (87.7\% water and $12.3 \%$ solids) in terms of cheese production. The production burden (at the dairy farm gate) for milk can be wholly assigned to the solids without differentiation (i.e., protein and fat assigned the same farm gate burden - water is considered only as a carrier), and the solids flow can be conceptually separated and treated as distinct inputs to the manufacturing system, allowing the solids content to be used as the mechanism for assigning the incoming milk burden to each coproduct (Feitz et al. 2007; Aguirre-Villegas et al. 2012). Allocation of the incoming milk solid burdens associated across the multiple coproducts based on milk solid distribution among the coproducts was our default approach (Fig. 2). In the plant survey, we requested each manufacturing facility operator to estimate the allocation of common utilities (electricity, natural gas, steam, etc.) to different operations within the plant boundary. Where this information was provided, we used it for plant-specific allocation of these inputs. For facilities that produce several types of cheese but have inputs without clearly identified fraction, the revenue associated with these sales were used to allocate the burdens among the cheeses.

\subsection{Life cycle inventory}

This LCA is comprehensive and includes all inputs to the dairy industry, from crop farming to the final disposition of the packaging at the end of the supply chain. However, the primary focus of this study was on processes within the control of cheese-manufacturing plants. For each participating plant, processing companies were asked to complete a spreadsheet-based survey to facilitate incorporation of the data. During 2010, data from 2009 operations were collected from a total of 17 processing plants, including 10 cheddar manufacturing facilities $(0.55$ million tons of cumulative production) and 6 mozzarella manufacturing facilities ( 0.35 million tons of cumulative production). The industry average life cycle inventory (LCI) data are available in the Electronic supplementary material of this paper. Based on US production estimates of 1.45 million tons/year of cheddar and 1.47 million tons/year of mozzarella (IDFA 2010), the study has a sample representing 38 and $24 \%$ of production, respectively. A variety of plant sizes are represented, with production ranging from 0.014 to 0.14 million tons of cheese/year. The survey requested facility-level data regarding purchases (materials and energy), production (cheese and other products), and emissions (solid and liquid waste streams). Previous work conducted by the investigators for the production of fluid milk to the farm gate was used as background for milk production (Thoma et al. 2012a, b). Data collected from primary sources were checked for validity by ensuring consistency of units for reporting and conversion as well as material balances to insure that all incoming milk solids are accounted for in products leaving the manufacturing facility. The ecoinvent pedigree matrix approach to assigning uncertainty of inputs was applied to unit processes generated from primary data. Secondary data were taken from the ecoinvent v2.2 database. The data quality pedigree provided by the ecoinvent center for these data was adopted without revision. If secondary data are not available, input-output LCI datasets from the Open IO database were used as a proxy (TSC, Open IO) (TSC 2012). SimaPro $\subset 7.3$ (PRé Consultants, The Netherlands 2012) was used as the primary modeling software; the ecoinvent database, modified to account for US electricity, provided information on the "upstream" burdens associated with materials such as fuels and plant chemicals. 


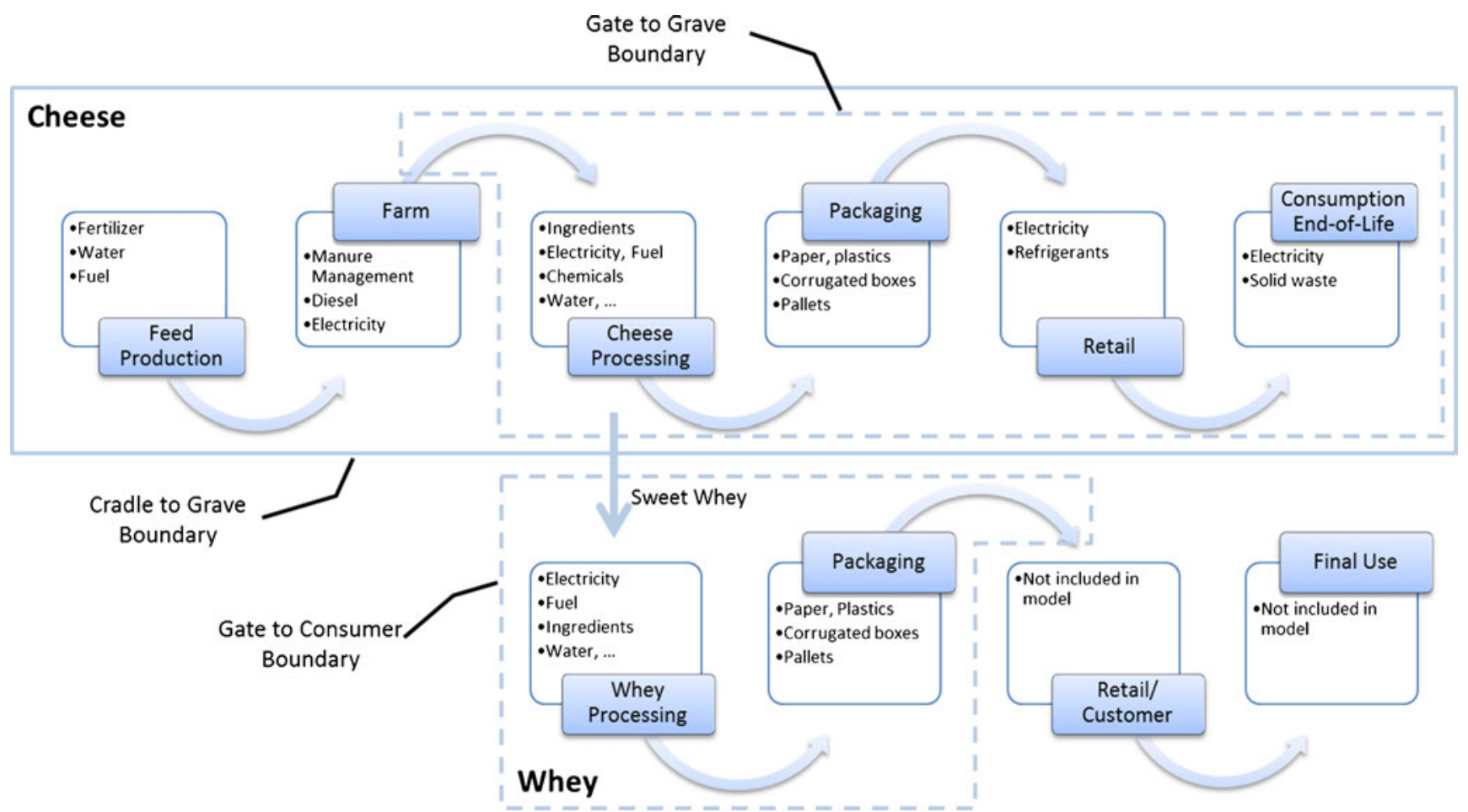

Fig. 1 Flow diagram depicting cheese and whey unit processes/operations, applicable to both cheddar and mozzarella processes. Note that the curved arrows represent a transport operation

\subsubsection{Cheese and whey plant data collection}

The plants within the study combined cheese and whey production. The survey requested information at the subfacility scale; however, in many cases, only facility-level data were available. For example, most plants reported a single annual electrical energy use. We requested engineering estimates for separate material and/or energy flows (inputs and outputs) associated solely with cheese or whey products. This information was used in the algorithm that allocated material and energy flows between the coproducts of cheese and whey (see Fig. 2). For this study, each output product of each plant was classified as one of the following: main cheese, other cheese, dry whey, wet whey, and other coproducts. Protection of confidential business information requires an aggregation of the data that were acquired from
Fig. 2 System separation for unique processes; milk solids, plant engineering estimates, and revenue-based approaches can be taken to allocate the common process burdens (Aguirre-Villegas et al. 2012)

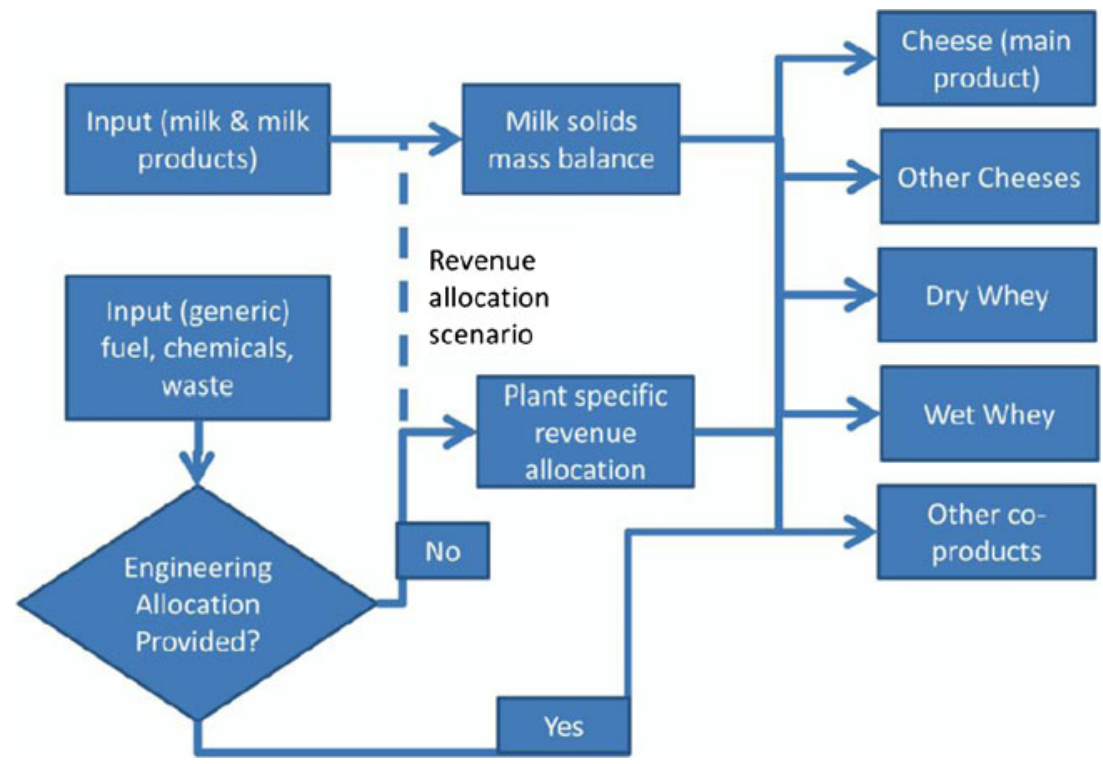


the manufacturing facilities that participated in this project. Representative average production LCI data were generated using the allocated LCI data for each plant, which was totaled to create a generic inventory for each of the five potential coproducts at each facility. The resultant inventory is a production-weighted dataset because each product's reference flow was the sum of production from all reporting facilities.

\subsubsection{Transportation: farm to manufacturing and manufacturing to retail}

The survey included information on transportation distances from farm to manufacturing facility and also for distribution to retail (or in the case of whey, to the first customer). These data were used to determine the impacts of these stages within the cheese supply chain. The baseline vehicle was considered to be an insulated tanker truck and a refrigerated truck for raw milk and finished product, respectively. For a refrigerated truck transport, we modified ecoinvent unit process by adding refrigerant loss (Nutter et al. 2012). Empty kilometers (during return) were also included. Allocation of transportation of the raw milk to different products was based on milk solids. Postmanufacturing transport was directly assigned to the product being transported.

\subsubsection{Retail}

Contribution to environmental impacts from the retail sector was assessed from information previously requested from the project sponsor, who provided data regarding shelf space occupied in retail grocery outlets coupled with publicly available data for energy consumption in the building sector (Energy Information Administration (EIA) 2003; Energy Star 2008). Disposal of secondary packaging was accounted for through recycling rates of the materials commonly recycled (corrugated packaging and pallets). After distribution from the processor to the retail gate, cheese is displayed for consumer purchase. During this phase, there are three distinct emissions streams: refrigerant leakage, refrigeration electricity, and overhead electricity. For the purposes of this LCA, cheese sales channels were divided into two primary channels: supermarkets and mass merchandisers. Estimates of the sales volume, space occupancy, and energy demands were used to determine the burden of this supply chain stage.

\subsubsection{Consumer transportation}

According to the US Department of Transportation, Bureau of Transportation Statistics, Research and Innovative Technology Administration's 2001 National Household Travel Survey (NHTS), the average household makes 88.4 trips annually of $10.8 \mathrm{~km}$ roundtrip for shopping (NHTS 2009). Allocation of impacts from this activity to cheese is
$1.16 \%$ (all cheese, $11.9 \%$ of dairy (USDA 2010); all dairy, $9.8 \%$ of grocery sales (Food Marketing Institute 2010)) resulting in $0.15 \mathrm{~km} / \mathrm{kg}$ cheese. The average number of people per household is assumed to be 2.6 (US Census Bureau 2009), and the per capita annual consumption of cheese is estimated to be 3.69 and $3.95 \mathrm{~kg}$ for cheddar and mozzarella, respectively. Therefore, the total annual household consumption was estimated to be 9.59 and $10.26 \mathrm{~kg}$ for cheddar and mozzarella, respectively. Considering all cheeses (excluding ricotta and cottage cheeses), annual household consumption is calculated at $28.9 \mathrm{~kg}$, resulting in 33.2 and $35.5 \%$ of all cheese consumption for cheddar and mozzarella, respectively. The transportation distances, then allocated to cheddar and mozzarella, are thus 0.050 and $0.054 \mathrm{~km} / \mathrm{kg}$ cheese purchased, respectively.

The average fuel economy for passenger cars and other four-wheel vehicles (pickup truck, sport utility vehicles) was determined from the NHTS (2009) to be 9.61 and $7.70 \mathrm{~km} / \mathrm{L}$, respectively. It was assumed that all personal vehicles are powered by gasoline. The National Automobile Dealers Association (NADA) State of the Industry Report (NADA 2011) reports a 50:50 market share ratio of passenger cars to other four-wheel vehicles. Therefore, a weighted average of $8.65 \mathrm{~km} / \mathrm{L}$ was assumed as the average fuel economy of personal vehicles. As the LCI datasets for personal transport in ecoinvent do not exactly match this fuel economy, we adjusted the number of kilometers of operation to ensure that the estimated fuel consumed, based on average US fuel economy, was properly calculated.

\subsubsection{Home refrigeration}

The EIA Residential Energy Consumption Survey estimates annual energy use for home refrigeration to be approximately $1,350 \mathrm{kWh}$ (EIA 2005). The cheese portion of the total refrigerated products, $2.57 \%$ (cheese, $11.9 \%$ of all dairy (USDA 2010); dairy, $21.7 \%$ of refrigerated sales (Food Marketing Institute 2010)), is used to calculate the home refrigeration attributable to cheese, which results in $34.7 \mathrm{kWh}$. Note that the refrigerated shelf space allocation at home is expected to be an overestimate: in-home shelf space occupied by cheese is likely smaller than at the store, since the fraction of shelf space occupied in-home is likely decreased due to items purchased at the store unrefrigerated that need refrigeration upon opening (e.g., ketchup). With these caveats, refrigeration energy per kilogram of all cheese at household is then estimated to be $1.2 \mathrm{kWh} / \mathrm{kg}$, and thus, 0.40 and $0.43 \mathrm{kWh} / \mathrm{kg}$ for cheddar and mozzarella, respectively, based on their market share.

\subsubsection{Dishwashing}

Water and energy burdens for dishwashing were taken from the Energy Star criteria for a standard-sized dishwasher 
model (Energy Star 2009). A standard-sized model is considered to use $1.51 \mathrm{kWh}$ and $22 \mathrm{~L}$ of water/cycle. It has a capacity of eight place settings and six serving pieces. A "place setting" is assumed to be comprised of two plates, one bowl, six utensils, and three glasses. Therefore, each cycle is assumed to wash 36 utensils ( 6 utensils $\times 6$ serving pieces) and 48 non-utensils ( 6 non-utensils $\times 8$ place settings). It is assumed that $10 \%$ of water and energy is allocated to the utensil rack and $90 \%$ to the non-utensil pieces. We assumed the dishwashing burden for utensils and plates for cheese consumption to be $5 \%$ of a dishwasher load $/ \mathrm{kg}$ cheese consumed. This assumption was based on an estimate of the mean number of plates and utensils used for cheese and the capacity of a typical dishwasher.

\subsubsection{Postconsumer solid waste}

We model waste disposal in SimaPro ${ }^{(C)}$ with unit processes from ecoinvent for consumer disposal of packaging material. Franklin Associates (2008) report that an estimated $14 \%$ of postconsumer waste is incinerated with energy recovery. We modeled the incineration of these materials but did not account for energy recovery, as it fell below the $1 \%$ cutoff criterion.

\subsection{Scenario analysis of cheddar aging}

The bulk of cheddar cheese sold in the USA is aged approximately 70 days, but specialty cheddar can be aged five or more years. In 2009, 1.45 million tons of cheddar cheese was produced in the USA (IDFA 2010). Cold holding reports for cheddar cheese were examined and a typical inventory of 0.28 million tons was reported (NASS 2010). Using a simple first in-first out assumption, the US inventory of cheddar cheese turns over 5.17 times a year (1.45/ $0.28=5.17$ ), implying that the typical age of cheddar cheese at retail is 70.6 days ( 365 days $/ 5.17=70.6$ days). Based on EIA (2003) survey data, refrigerated warehouses consume an average of $307 \mathrm{kWh} / \mathrm{m}^{2} /$ year of electricity and $338 \mathrm{MJ} / \mathrm{m}^{2} /$ year of natural gas. We assumed that pallets were stored on shelves up to six pallets high (typical warehouse height $=\sim 9 \mathrm{~m}$ ) and used an industry estimate of the number of $18.1 \mathrm{~kg}$ (40-lb) blocks in 45 blocks per pallet. Ammonia is used for refrigeration in large warehouses used for cheese storage. We used an emission factor of $13.6 \mathrm{~kg}$ $\mathrm{NH}_{3}$ /employee/year coupled with Industrial Assessment Center (IAC 2009) data on employees and warehouse size to arrive at an estimated emission of $0.013 \mathrm{~kg} \mathrm{NH} \mathrm{NH}_{3} / \mathrm{m}^{2} /$ day of storage. Mozzarella is distributed for retail as rapidly as possible, but typically, needs to be held for 2 weeks before unwrapping to smaller pieces and repackaging to retail sizes. It should be noted that a large fraction of mozzarella is used in food service applications where it is frozen and stored for some time prior to being used. We did not include this branch of the supply chain as our focus was on cheese directly purchased by the end consumer.

\subsection{Life cycle impact assessment}

The intention of this study was to provide a comprehensive environmental life cycle impact assessment (LCIA) of cheese production and consumption, which stems from all phases of cheese production and delivery systems. These environmental impacts include climate change, cumulative energy demand, freshwater depletion, marine and freshwater eutrophication, photochemical oxidant formation, impacts to ecosystems and human toxicity, and ecotoxicity (Hertwich et al. 1998; Huijbregts et al. 2000; Jolliet et al. 2003; Goedkoop et al. 2009; Hischier and Weidema 2010). We chose impact categories relevant to the dairy industry: IPCC GWP 100a, Cumulative Energy Demand, ReCiPe Midpoint, ReCiPe Endpoint, and USEtox (Table 1).

\section{Results and discussion}

\subsection{Life cycle impact assessment results}

We accounted for the entire supply chain of cheese consumption in the USA. This includes specifically product loss at various stages of the supply chain, as well as consumer transport and storage of products prior to consumption. Figures 3 and 4 present a contribution analysis of cradle-to-grave (left column) and farm gateto-grave (right column) LCIA results across all of the impact categories considered for cheddar and mozzarella, respectively. Figure 5 presents a summary of cradleto-gate and farm gate-to-gate LCIA results for dry whey. Quantitative results are presented in Tables 2

Table 1 Reporting categories used for the study

\begin{tabular}{ll}
\hline Life cycle inventory categories & Life cycle impact categories \\
\hline Cumulative energy demand & Climate change \\
Freshwater depletion & Marine eutrophication \\
& Photochemical oxidant formation \\
& Freshwater eutrophication \\
& Ecosystems \\
& Human toxicity \\
& Ecotoxicity \\
\hline
\end{tabular}



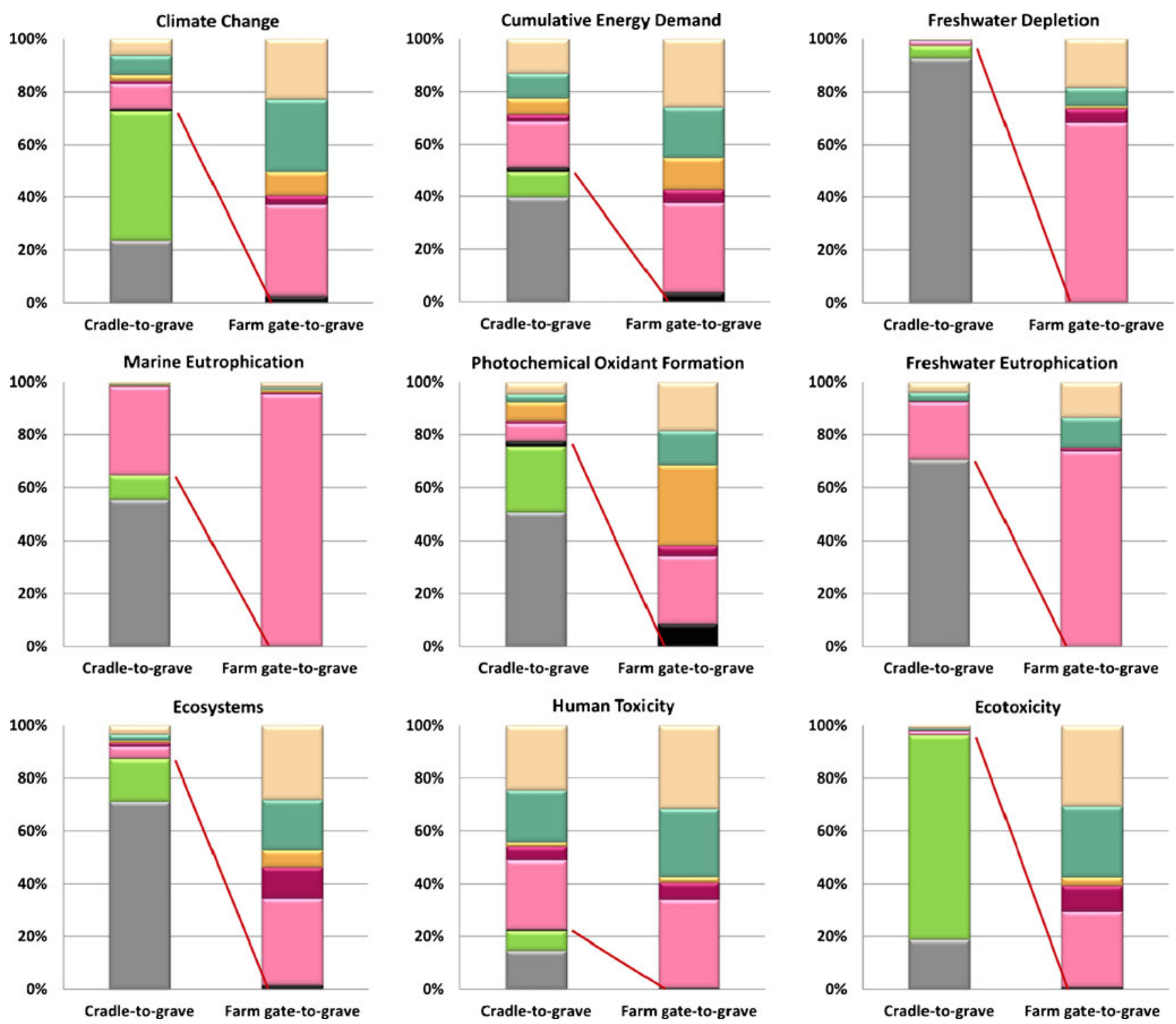

Legend:
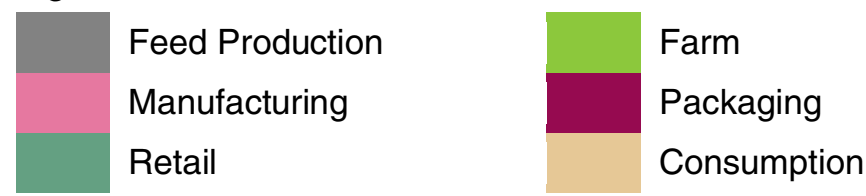

Raw Milk Transport

Distribution

Fig. 3 Contribution analysis of cradle-to-grave (left column) and farm gate-to-grave (right column) LCIA results for cheddar cheese supply chain

and 3 for cheddar and mozzarella, respectively. It is not surprising that, for most of the impact categories, the production of milk dominates the environmental impacts of cheese production. Cumulative energy demand and human toxicity are the only two categories for which $50 \%$ or more of the impact occurs after the farm gate. This can be explained by the relatively even distribution of electricity consumption across the supply chain compared to the more intense pre-farm gate activities that affect the remaining impact categories.

\subsubsection{Feed production and on-farm impacts}

We found that raw milk impacts from feed production and farm milk production are similar for each manufactured product (cheddar, mozzarella, and dry whey). Both are 

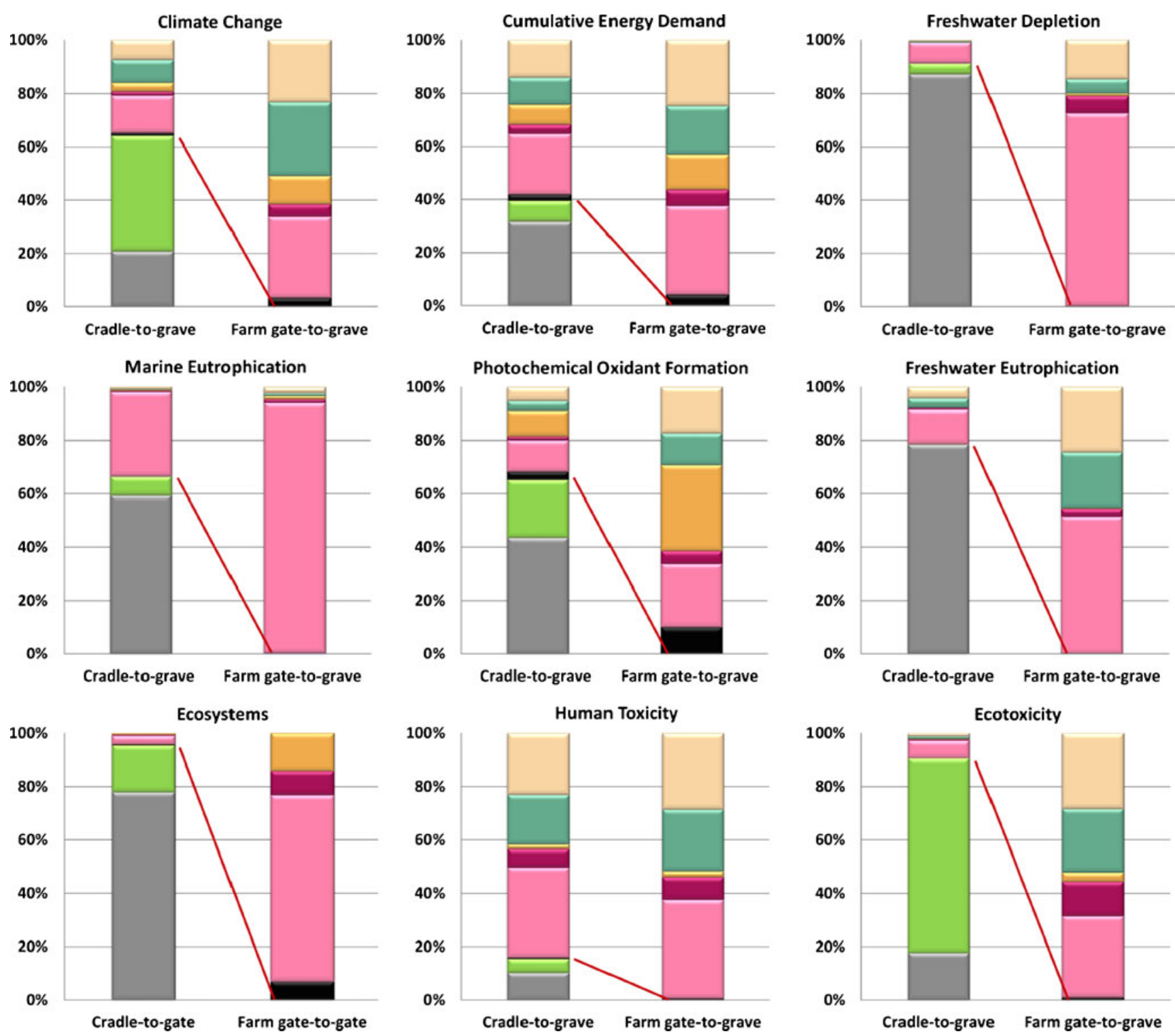

Legend:
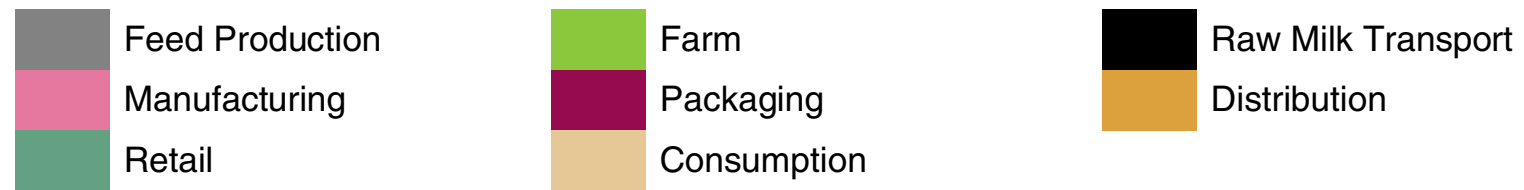

Fig. 4 Contribution analysis of cradle-to-grave (left column) and farm gate-to-grave (right column) LCIA results for mozzarella cheese supply chain

significant contributors across all impact categories (Table 4).

\subsubsection{Farm gate-to-gate impacts}

Environmental impacts associated with foreground LCA processes are those that can be more readily controlled by the cheese manufacturer and span the supply chain from the dairy farm gate to the first customer. It is noted that impacts in climate change and cumulative energy demand are significantly driven by electricity and natural gas consumption (Fig. 6). Cumulative energy demand normally tracks GHG emissions. However, milk production has a significant contribution from enteric methane, and therefore, the relative consumption of fossil fuel is lower. Eutrophication impacts are dominated by on-site wastewater treatment (WWT). In 

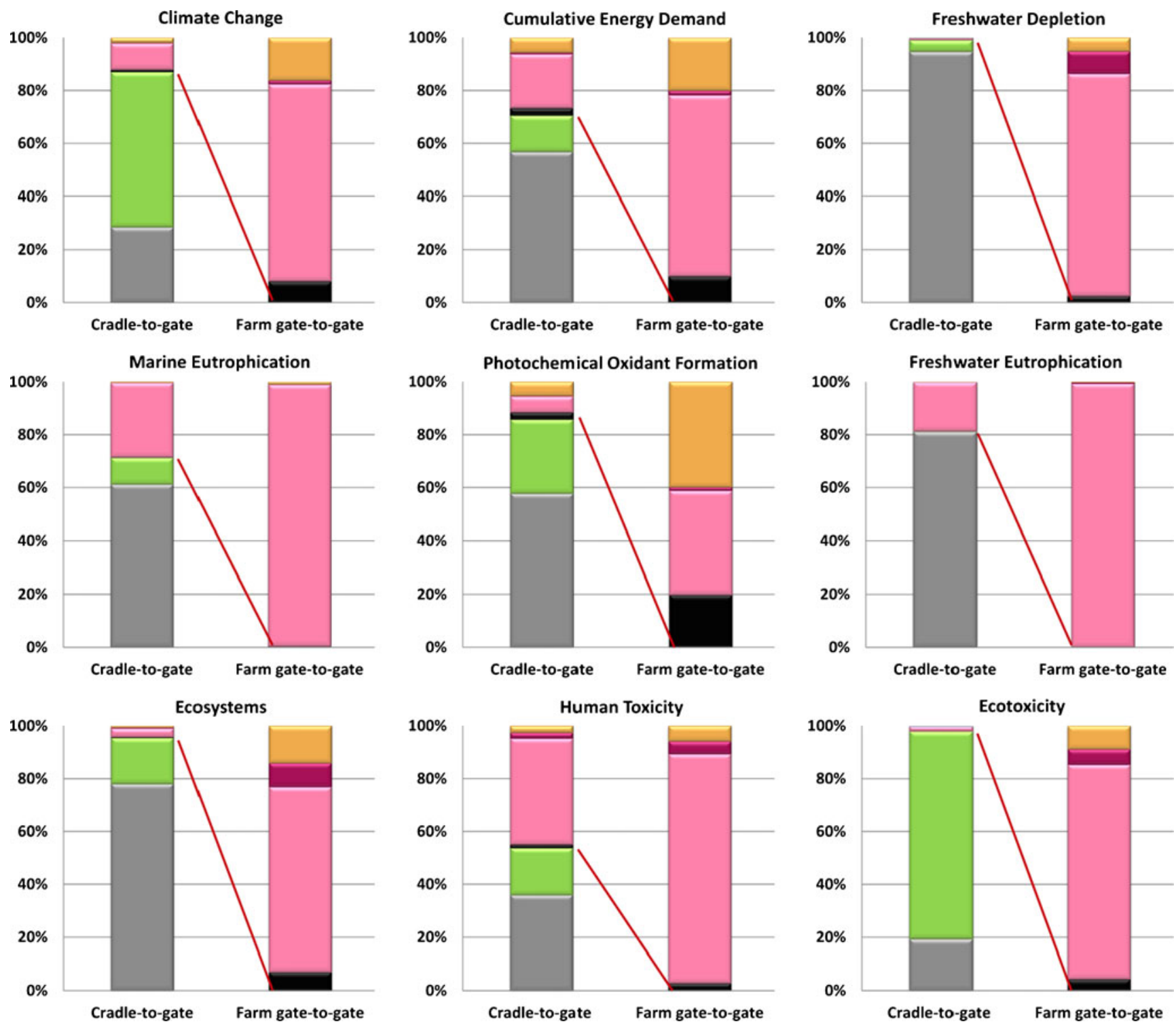

Legend:
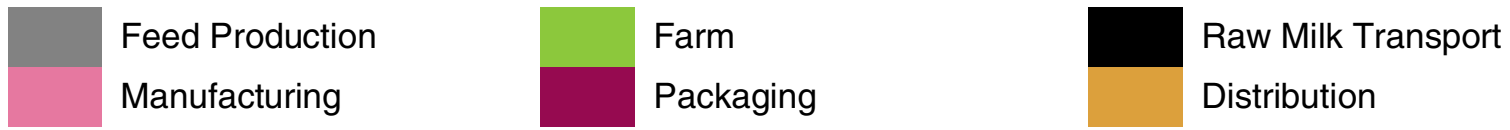

Fig. 5 Contribution analysis of cradle-to-customer-gate (left column) and farm gate-to-customer-gate (right column) LCIA results for dry whey supply chain

this model, WWT is taken from the ecoinvent database and assumes a loading of nitrogen and phosphorus that may not be representative of individual plants in the US industry. Some facilities reported significantly lower phosphorous loadings, while others reported significantly higher loadings. Based on the survey data and literature reports, we modified the ecoinvent dataset to remove contributions from sludge incineration, to the extent that it could be singled out, and reduced the estimated influent phosphorus concentration from $250 \mathrm{mg} / \mathrm{L}$ (Swiss conditions) to
$70 \mathrm{mg} / \mathrm{L}$. It is necessary to have more site-specific information to draw conclusions about individual facilities. Photochemical oxidant formation is strongly influenced by transportation. The impacts to human toxicity and ecotoxicity are dominated by electricity use (arsenic and other heavy metals emissions from coal mining activities) . The relative contributions to cheddar and mozzarella impacts are nearly identical on a dry solids basis because the technologies are fairly similar. Thus, mozzarellaspecific results are not included here. 


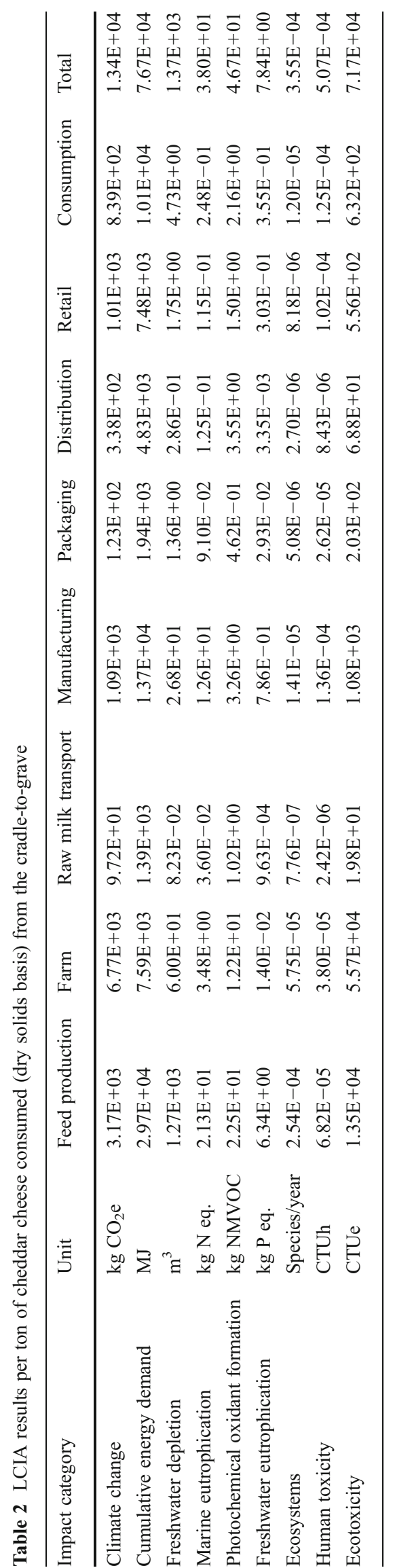

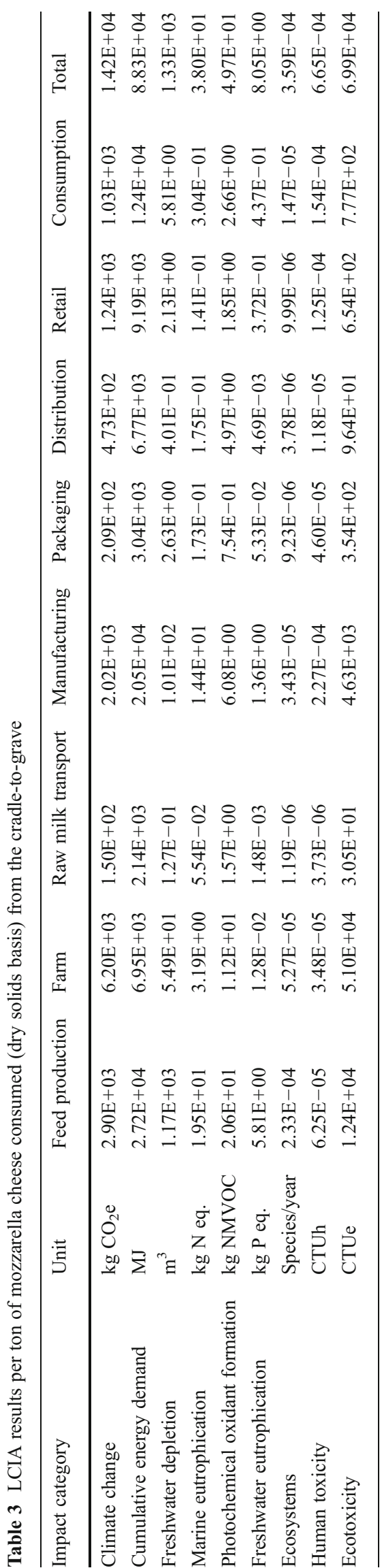


Table 4 The largest impact drivers for feed production and on-farm activities

\begin{tabular}{|c|c|}
\hline Impact category & Impact drivers \\
\hline Climate change & $\begin{array}{l}\text { Farm-based enteric methane and manure management; farm } \mathrm{CO}_{2} \text { from fossil fuels combustion (cultivation } \\
\text { and on-farm usage); and } \mathrm{N}_{2} \mathrm{O} \text { from fertilizer application and manure management }\end{array}$ \\
\hline Cumulative energy demand & Natural gas, oil, and coal for direct use and production of nitrogen fertilizer \\
\hline Freshwater depletion & Majority of irrigation $(95 \%)$ and lesser amount toward milking parlor cleaning and livestock watering \\
\hline Marine eutrophication & Phosphate release from runoff due to on-field fertilizer application \\
\hline Photochemical oxidant formation & $\begin{array}{l}\mathrm{NO}_{x} \text { and VOCs from combustion (a significant source in some regions is ethanol released during } \\
\text { fermentation of silage) }\end{array}$ \\
\hline Freshwater eutrophication & $\begin{array}{l}\text { Nitrogen compound runoff from fertilizer application and manure management; eutrophication is } \\
\text { geospatially variable and dependent on local conditions }\end{array}$ \\
\hline Ecosystems & $\begin{array}{l}\text { Land occupation for crop production and crop/farm GHG emissions; land occupation is often } \\
\text { considered a surrogate indicator for biodiversity }\end{array}$ \\
\hline Human toxicity & $\begin{array}{l}\text { Arsenic to water and heavy metals (in both air and water) primarily from coal mining tailings and } \\
\text { coal ash disposal in the electricity supply chain }\end{array}$ \\
\hline Ecotoxicity & $\begin{array}{l}\text { Pesticides for crop and livestock protection; insecticide applied as a back pour for fly and lice control } \\
\text { in dairy cattle contributes significantly of the total aquatic ecotoxic impact }\end{array}$ \\
\hline
\end{tabular}

\subsection{Normalization}

This is an optional phase of an LCA according to ISO 14044 , but it is a useful step to help identify impact categories that are particularly relevant for the industry under study. Briefly, normalization is an effort to contextualize the emissions impacts, typically on a regional basis. The total emissions contributing to a specific impact category for the region are estimated and then normalized to a per person basis for the region. Thus, a normalization factor will have units of impact per person per year and represents the average cumulative impacts in the region on a per capita basis. Normalization factors have been recently published for the USA for IMPACT 2002+ (Lautier et al. 2010). Comparison of impact categories from different methods is a valuable qualitative exercise. However, caution should be taken in making direct quantitative comparisons because there are differences in the underlying methods, and characterization of the same substance in different frameworks is not exactly the same. Some of these differences arise due to
Fig. 6 Relative contribution of manufacturing inputs to environmental impacts from farm gate-to-customer for cheddar cheese production

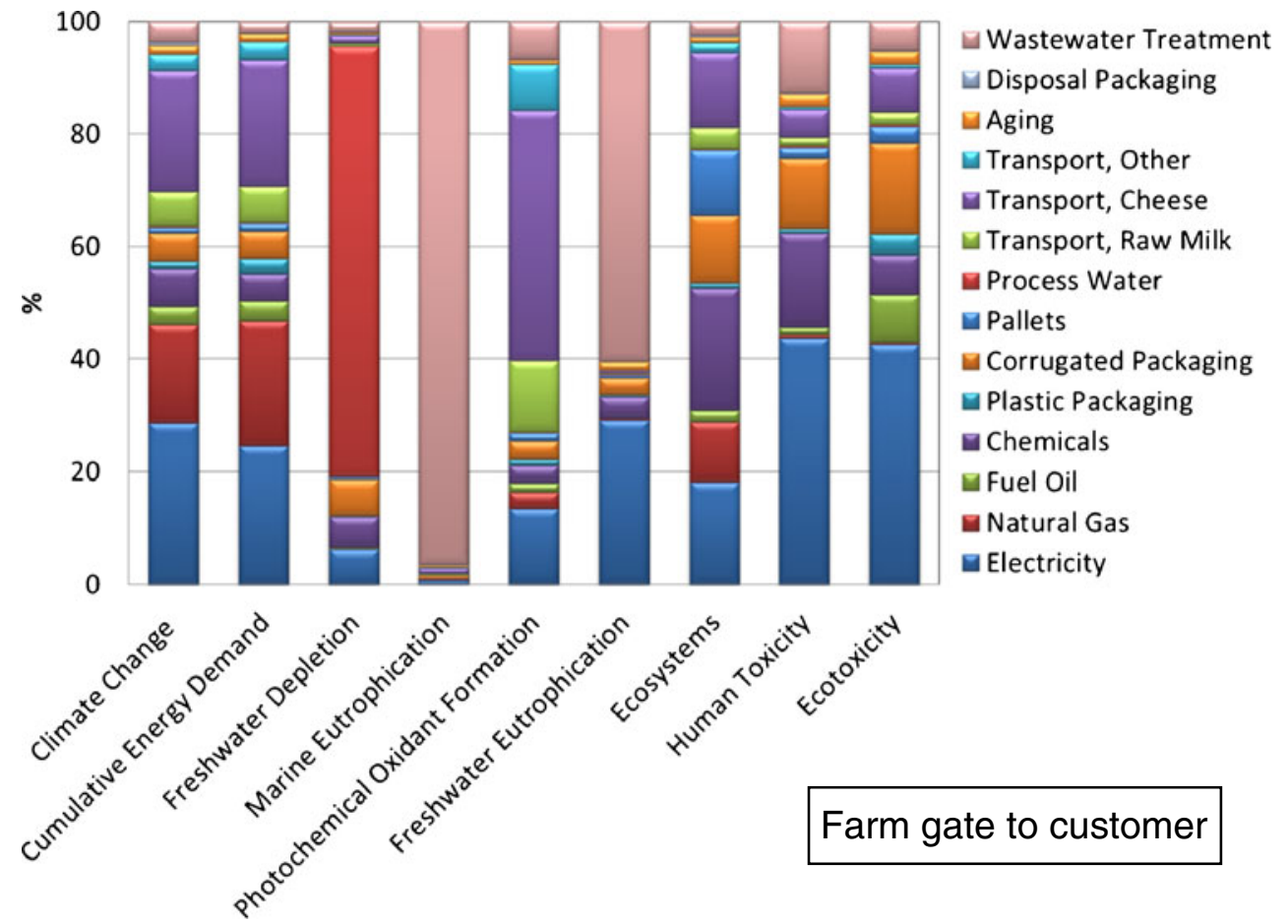


Fig. 7 US normalization of cradle-to-grave impacts for the consumption of $3.7 \mathrm{~kg}(63.2 \%$ solids) cheddar cheese using normalization factors provided by Lautier et al. (2010) for the IMPACT 2002+ LCIA framework

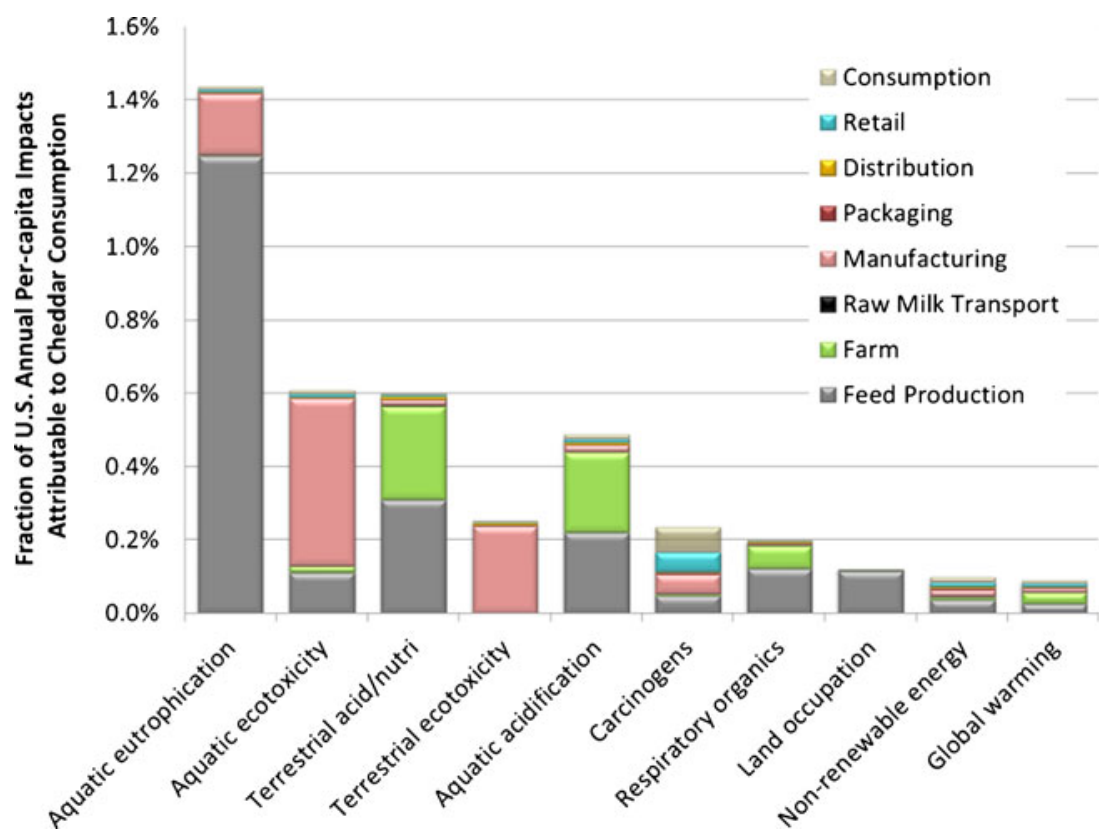

the geographic domain of the framework, while other differences represent uncertainty in, for example, the toxicology of a particular compound or whether a receiving water body is phosphorus-limited or nitrogenlimited in the case of eutrophication. In the following discussion, each of two normalization tests was conducted using the reported (USDA 2010) annual lossadjusted cheese consumption of an average US citizen, $3.67 \mathrm{~kg}$ cheddar $(2.32 \mathrm{~kg}$ on a dry solids basis $)$ or $3.95 \mathrm{~kg}$ mozzarella (2.03 $\mathrm{kg}$ on a dry solids basis).

\subsubsection{IMPACT 2002+ US midpoint normalization}

We conducted a normalization test using the IMPACT $2002+$ assessment framework. The emissions from the system are compared to the average per capita emissions, enabling mitigation efforts to focus on the impact categories that contribute the largest relative fraction of environmental impact. There is not an exact correspondence between the IMPACT 2002+ framework and the combination of ReCiPe and USEtox chosen for this study, but US normalization
Fig. 8 Normalized cradle-tograve impacts for the consumption of $3.7 \mathrm{~kg}$ cheddar by US consumers. ReCiPe Endpoint impacts with World Hierarchist normalization

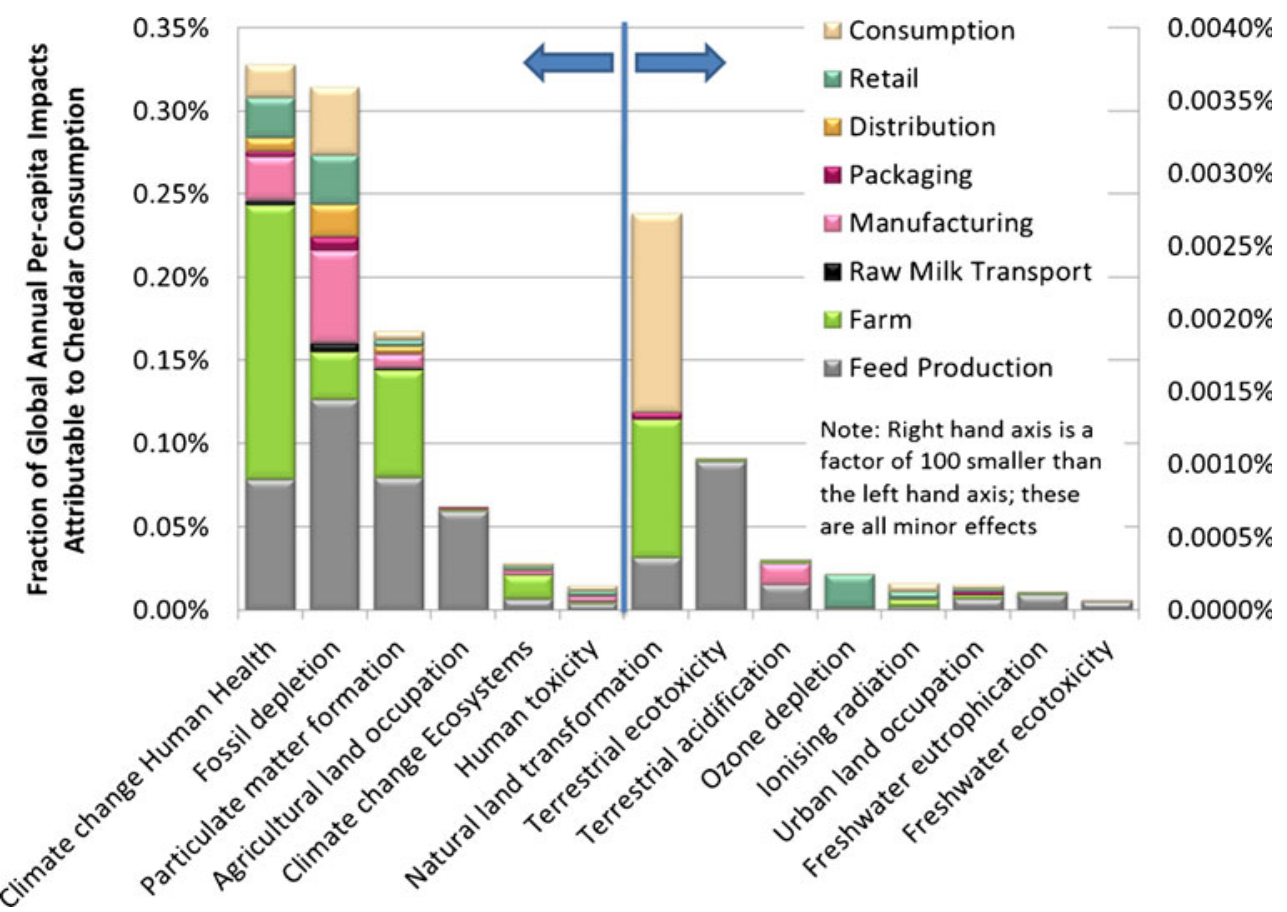


Table 5 Percent increase in cradle-to-grave and post-farm gate impacts (in parentheses) from 1 to 60 months cheddar aging in refrigerated warehouse (the baseline scenario assumed $\sim 70.6$ days total aging, if manufacturing plants hold 10-14 days-values in this table are for total aging time)
Impact category

Climate change

Cumulative energy demand

Freshwater depletion

Marine eutrophication

Photochemical oxidant formation

Freshwater eutrophication

Ecosystems

Human toxicity

Ecotoxicity

\begin{tabular}{lll}
\multicolumn{3}{l}{ Months of additional aging, \% (\%) } \\
1 & 2 & 12 \\
$0.09(0.37)$ & $0.19(0.73)$ & $1.1(4.4)$ \\
$0.22(0.43)$ & $0.44(0.87)$ & $2.6(5.2)$ \\
$0.00(0.13)$ & $0.00(0.25)$ & $0.03(1.5)$ \\
$0.06(0.18)$ & $0.12(0.36)$ & $0.75(2.2)$ \\
$0.06(0.26)$ & $0.13(0.52)$ & $0.77(3.1)$ \\
$0.07(0.41)$ & $0.15(0.83)$ & $0.89(5.0)$ \\
$0.03(0.26)$ & $0.06(0.52)$ & $0.36(3.1)$ \\
$0.39(0.50)$ & $0.78(1.0)$ & $4.7(6.0)$ \\
$0.01(0.50)$ & $0.03(1.0)$ & $0.17(6.0)$
\end{tabular}

$$
24
$$$$
2.2(8.8)
$$$$
36
$$$$
3.3 \text { (13) }
$$$$
5.3 \text { (10) }
$$$$
7.9 \text { (16) }
$$$$
0.06(3.0)
$$$$
0.08(4.5)
$$$$
1.5 \text { (4.4) }
$$$$
2.2(6.6)
$$$$
1.5(6.2)
$$$$
2.3(9.3)
$$$$
2.7 \text { (15) }
$$$$
1.1(9.4)
$$$$
0.71(6.2)
$$$$
14 \text { (18) }
$$$$
9.4(12)
$$$$
0.51 \text { (18) }
$$

48

4.5 (18)

11 (21)

$0.11(6.0)$

$3.0(8.7)$

3.1 (12)

3.6 (20)

1.4 (12)

19 (24)

0.69 (24)
60

$5.6(22)$

13 (26)

$0.14(7.5)$

3.7 (11)

3.9 (15)

4.5 (25)

1.8 (16)

23 (30)

$0.86(30)$ factors do not exist for those methods. The example normalization results for cheddar (Fig. 7) indicate that aquatic eutrophication, aquatic ecotoxicity, and terrestrial acidification are important categories on which to focus improvement activities. From a manufacturing perspective, these can be mitigated through energy conservation and water conservation/treatment activities.

\subsubsection{ReCiPe world endpoint normalization}

The ReCiPe method presents an alternate view of normalization of cheddar impacts (Fig. 8). In this approach, the region under consideration is the globe. Thus, the $y$-axis represents the impact that a US resident's consumption of cheese imposes on the environment compared to an average impact of all people on the planet (from all sources contributing to that impact category). It is well-documented that the USA consumes a disproportionate amount of resources compared to the majority of the world. The global normalization approach, based on an endpoint perspective, which accounts for the effects of, for example, climate change on human health, suggests that US annual consumption of natural cheese is a more important driver of climate change health effects, respiratory effects resulting from particulateforming emissions and fossil fuel depletion, with relatively lower importance in the remaining categories. It should be noted that the set of impacts two orders of magnitude smaller than the others (see Fig. 8) should have lower priority for reduction. It is of course important to make incremental improvements in all impact categories, and efforts to reduce electricity and fossil fuel consumption will have broad benefits.

\subsection{Scenario analysis of cheddar aging}

To understand the potential impacts associated with longterm aging of cheddar, we conducted a scenario study with cold storage up to 5 years. We present the results for both cradle-to-grave and post-farm gate (Table 5). In terms of GHG emissions after 60 months of aging, there is approximately 6 and $22 \%$ increase (an increase of $0.47 \mathrm{~kg}$ $\mathrm{CO}_{2} \mathrm{e} / \mathrm{kg}$ dry cheese solids) in the cradle-to-grave and farm gate-to-grave emissions, respectively. For the post-farm supply chain, human toxicity and ecotoxicity impacts increase noticeably, primarily associated with increased electricity use for additional refrigeration.
Table 6 Results of 1,000 Monte Carlo simulations for uncertainty analysis of cheddar cheese from cradle-to-grave per ton of dry cheese solids

\begin{tabular}{lllccc}
\hline Impact category & Unit & Mean & $\begin{array}{l}\text { Coefficient of } \\
\text { variation }(\mathrm{CV})(\%)\end{array}$ & $95 \% \mathrm{CI}$ \\
\hline Climate change & $\mathrm{kg} \mathrm{CO} \mathrm{e}$ & $1.34 \mathrm{E}+04$ & 18.8 & $9.28 \mathrm{E}+03$ & $1.93 \mathrm{E}+04$ \\
Cumulative energy demand & $\mathrm{MJ}$ & $7.67 \mathrm{E}+04$ & 46.1 & $4.73 \mathrm{E}+04$ & $1.57 \mathrm{E}+05$ \\
Freshwater depletion & $\mathrm{m}^{3}$ & $1.37 \mathrm{E}+03$ & 21.8 & $8.88 \mathrm{E}+02$ & $2.06 \mathrm{E}+03$ \\
Marine eutrophication & $\mathrm{kg} \mathrm{N}$ eq. & $3.80 \mathrm{E}+01$ & 18.3 & $2.65 \mathrm{E}+01$ & $5.42 \mathrm{E}+01$ \\
Photochemical oxidant & $\mathrm{kg} \mathrm{NMVOC}$ & $4.67 \mathrm{E}+01$ & 17.7 & $3.22 \mathrm{E}+01$ & $6.54 \mathrm{E}+01$ \\
$\quad$ formation & & & & & \\
Freshwater eutrophication & $\mathrm{kg} \mathrm{P}$ eq. & $7.84 \mathrm{E}+00$ & 18.7 & $2.41 \mathrm{E}-04$ & $5.15 \mathrm{E}-04$ \\
Ecosystems & Species/year & $3.55 \mathrm{E}-04$ & 27.7 & $4.95 \mathrm{E}+00$ & $1.22 \mathrm{E}+01$ \\
Human toxicity & CTUh & $5.07 \mathrm{E}-04$ & 211 & $1.81 \mathrm{E}-04$ & $1.38 \mathrm{E}-03$ \\
Ecotoxicity & CTUe & $7.17 \mathrm{E}+04$ & 22.4 & $4.78 \mathrm{E}+04$ & $1.06 \mathrm{E}+05$ \\
\hline
\end{tabular}


Table 7 Results of 1,000 Monte Carlo simulations for uncertainty analysis of mozzarella cheese from cradle-to-grave per ton of dry cheese solids

\begin{tabular}{llllll}
\hline Impact category & Unit & Mean & CV (\%) & $95 \% \mathrm{CI}$ & \\
\hline Climate change & $\mathrm{kg} \mathrm{CO} \mathrm{e}$ & $1.42 \mathrm{E}+04$ & 17.0 & $9.73 \mathrm{E}+03$ & $1.96 \mathrm{E}+04$ \\
Cumulative energy demand & $\mathrm{MJ}$ & $8.83 \mathrm{E}+04$ & 41.1 & $5.01 \mathrm{E}+04$ & $1.69 \mathrm{E}+05$ \\
Freshwater depletion & $\mathrm{m}^{3}$ & $1.33 \mathrm{E}+03$ & 20.1 & $8.81 \mathrm{E}+02$ & $1.94 \mathrm{E}+03$ \\
Marine eutrophication & kg N eq. & $3.80 \mathrm{E}+01$ & 16.9 & $2.64 \mathrm{E}+01$ & $5.20 \mathrm{E}+01$ \\
Photochemical oxidant formation & kg NMVOC & $4.97 \mathrm{E}+01$ & 16.7 & $3.45 \mathrm{E}+01$ & $6.65 \mathrm{E}+01$ \\
Freshwater eutrophication & kg P eq. & $8.05 \mathrm{E}+00$ & 16.8 & $2.47 \mathrm{E}-04$ & $4.84 \mathrm{E}-04$ \\
Ecosystems & Species/year & $3.59 \mathrm{E}-04$ & 26.7 & $4.99 \mathrm{E}+00$ & $1.26 \mathrm{E}+01$ \\
Human toxicity & CTUh & $6.65 \mathrm{E}-04$ & 95.2 & $2.57 \mathrm{E}-04$ & $1.71 \mathrm{E}-03$ \\
Ecotoxicity & CTUe & $6.99 \mathrm{E}+04$ & 20.1 & $4.60 \mathrm{E}+04$ & $9.98 \mathrm{E}+04$ \\
\hline
\end{tabular}

\subsection{Plant-scale variability}

Figure 9 presents a summary comparison of the ten cheddar and six mozzarella plants that provided data for this study to present the full variability of operations. The LCIA was normalized so that the average mozzarella plant equaled 100. Caution in interpreting this variability is necessary because each facility is considered in its totality, with no allocation between multiple products. The impacts are based on a reference flow of the total milk solids processed regardless of the quantity of cheese, whey, or other products manufactured. It is apparent that there is significant variability among the plants and that there are opportunities for many of them to improve. Due to the nature of the survey data collected (i.e., at the plant scale), it is not possible in this study to identify which unit operations may be causing the differences among the facilities, and additional subfacility data collection and analysis will be necessary to fully identify and target unit operations for improvement.

\subsection{Limitations}

The variability associated with the allocation procedure used for the study places some limits on the recommendations that can be supported for specific products. This work is intended to provide a benchmark for the industry, and for whole-plant analysis, this has been achieved. However,
Table 8 Results of 1,000 Monte Carlo runs for uncertainty analysis of dry whey from cradle-tocustomer per ton of dry whey solids

\begin{tabular}{llllll}
\hline Impact category & Unit & Mean & CV (\%) & $95 \% \mathrm{CI}$ & \\
\hline Climate change & $\mathrm{kg} \mathrm{CO}_{2} \mathrm{e}$ & $1.21 \mathrm{E}+04$ & 15.3 & $9.11 \mathrm{E}+03$ & $1.61 \mathrm{E}+04$ \\
Cumulative energy demand & $\mathrm{MJ}$ & $5.81 \mathrm{E}+04$ & 28.5 & $4.09 \mathrm{E}+04$ & $8.93 \mathrm{E}+04$ \\
Freshwater depletion & $\mathrm{m}^{3}$ & $1.45 \mathrm{E}+03$ & 16.2 & $1.05 \mathrm{E}+03$ & $2.00 \mathrm{E}+03$ \\
Marine eutrophication & $\mathrm{kg} \mathrm{N}$ eq. & $3.73 \mathrm{E}+01$ & 12.2 & $2.92 \mathrm{E}+01$ & $4.77 \mathrm{E}+01$ \\
Photochemical oxidant formation & kg NMVOC & $4.40 \mathrm{E}+01$ & 12.9 & $3.33 \mathrm{E}+01$ & $5.60 \mathrm{E}+01$ \\
Freshwater eutrophication & kg P eq. & $7.52 \mathrm{E}+00$ & 15.6 & $5.53 \mathrm{E}+00$ & $1.01 \mathrm{E}+01$ \\
Ecosystems & Species/year & $3.51 \mathrm{E}-04$ & 13.4 & $2.70 \mathrm{E}-04$ & $4.54 \mathrm{E}-04$ \\
Human toxicity & CTUh & $2.27 \mathrm{E}-04$ & 116 & $7.78 \mathrm{E}-05$ & $7.29 \mathrm{E}-04$ \\
Ecotoxicity & CTUe & $7.57 \mathrm{E}+04$ & 14.9 & $5.69 \mathrm{E}+04$ & $1.01 \mathrm{E}+05$ \\
\hline
\end{tabular}


Fig. 9 Comparison of farm gate-to-grave impacts of cheese-manufacturing facilities reported for this study. The average mozzarella facility is shown in black and average cheddar in gray. All facilities are normalized to the average mozzarella plant defined as 100. Individual plant scores are sorted in descending order to preserve the confidentiality of individual plant data

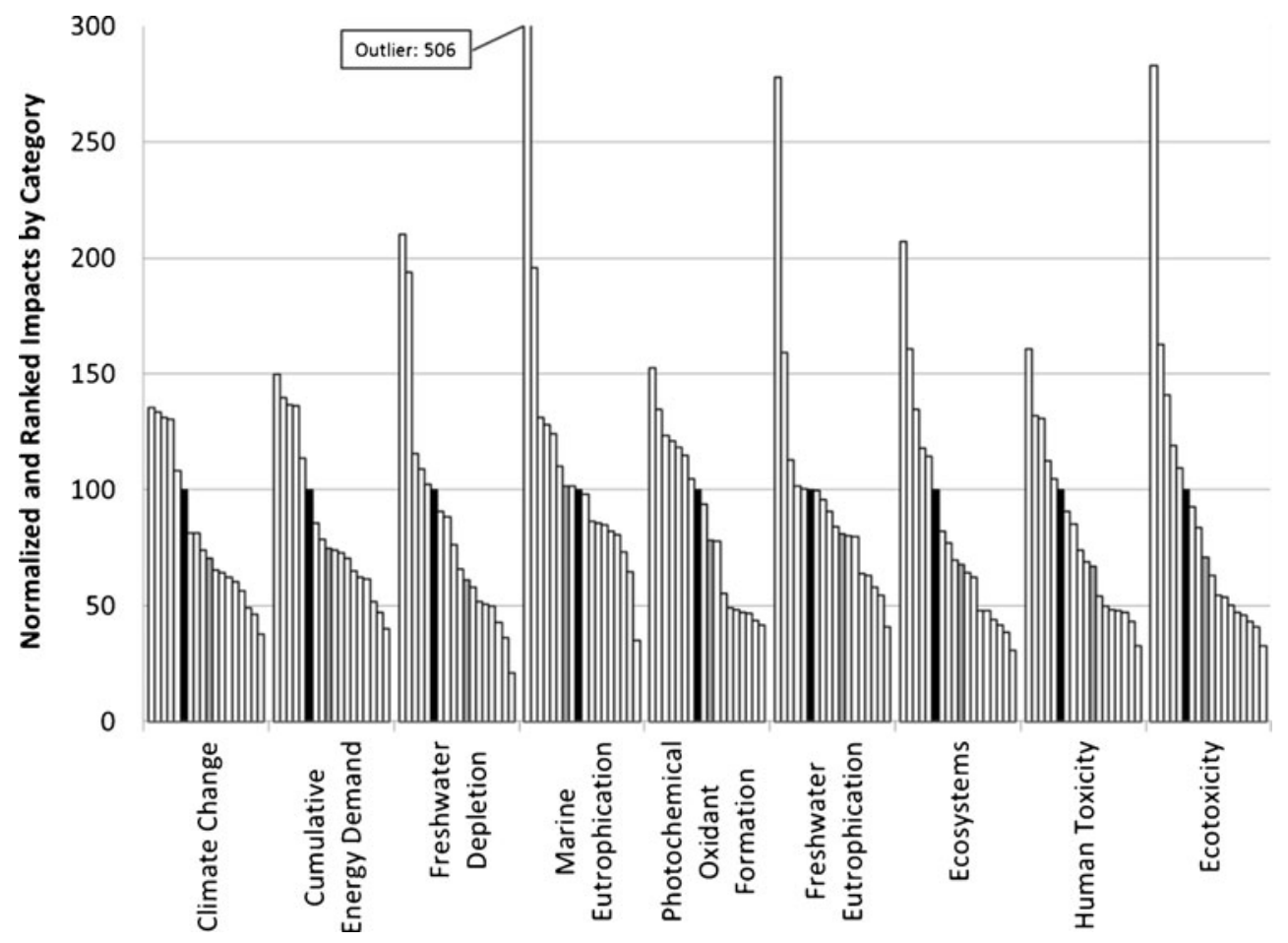

there were variations in the reported allocation of in-plant resource use. Without a detailed process model for each plant, a generic allocation is difficult to achieve. In addition, some data quality concerns exist regarding the completeness of the milk solid mass fractions. Thus, while the results are in good general agreement with available European studies, public statements regarding the footprint of cheese alone or whey alone should be made cautiously due to the individual allocation fractions of each plant studied.

\section{Conclusions and recommendations}

This study was a US-based LCA for cheddar cheese, mozzarella cheese, and associated whey products. A combination of LCI and LCIA were reported to help the cheese industry engage in sustainable practices and reduce environmental impacts, while validating those reductions by benchmarking their performance against a 2009 industry average. Primary focus was placed on the processes within the control of cheese-manufacturing plants.

Climate change and cumulative energy demand impacts are closely linked to fossil fuel consumption. Moreover, many other environmental impacts from the post-farm manufacturing and distribution stages of the production of cheddar cheese and mozzarella cheese are also directly linked to energy consumption primarily that associated with coal mining and combustion.

The production of raw milk is the major contributor to nearly all impact categories; thus, efforts to reduce milk/cheese loss at all stages in the supply chain have significant potential to reduce the overall impacts of cheese consumption. In addition, on-farm mitigation efforts around enteric methane, manure management, phosphate and nitrate runoff, and pesticides used on crops and livestock also have the potential to significantly reduce overall impacts.

Water-related impacts such as depletion and eutrophication can be considered as resource management issues - in the case of depletion, management of water quantity, and in the case of eutrophication, management of nutrients. Thus, opportunities for water conservation across the supply chain should be evaluated, and cheese manufacturers, while not having control over the largest fraction of water consumption, can begin to investigate the water use efficiency of the milk they procure.

The regionalized normalization analysis based on an average US citizen's annual cheese consumption showed that eutrophication represents the largest relative impact due largely to the combination of phosphorus runoff from agricultural fields and phosphorous emissions associated with digestion of wastewater from whey processing. Therefore, incorporating best practices around phosphorous and nitrogen management could yield improvements.

Finally, the US electricity supply chain (primarily coalbased) and combustion of other fossil fuels (natural gas, diesel, etc.) were also found to be the primary contributors to photochemical oxidant formation, impacts to ecosystems, human toxicity, and ecotoxicity. Thus, conservation efforts to reduce fuel and electricity use within the cheese life cycle will have broad beneficial impacts, both economic, through 
cost savings, and environmental, due to the reduction in emissions.

Acknowledgments The authors appreciate the support and cooperation of the Innovation Center for U.S. Dairy by providing funding, participating the interpretation and providing opportunities to interact with major cheese-manufacturing facilities. The Innovation Center also supports open access availability to advance research studies. The authors also thank three ISO panel reviewers for their constructive comments.

Open Access This article is distributed under the terms of the Creative Commons Attribution License which permits any use, distribution, and reproduction in any medium, provided the original author(s) and the source are credited.

\section{References}

Aguirre-Villegas HA, Milani FX, Kraatz S, Reinemann DJ (2012) Life cycle impact assessment and allocation methods development for cheese and whey processing. A Soc Agricul Biol Eng 55(2):613-627

Berlin J (2002) Environmental life cycle assessment (LCA) of Swedish semi-hard cheese. Int Dairy J 12(11):939-953

Berlin J (2005) Environmental improvements of the post-farm dairy chain: production management by systems analysis methods. Dissertation, Chalmers University of Technology, Göteborg, Sweden

Berlin J, Sonesson U, Tillman AM (2007) A life cycle based method to minimise environmental impact of dairy production through product sequencing. J Cleaner Prod 15:347-356

Bianconi P, Marani S, Masoni P, Raggi A, Sara B, Scartozzi D, Tarantini M (1998) Application of life-cycle assessment to the italian dairy industry: a case-study. Proceedings of the International Conference on Life Cycle Assessment in Agriculture, Agro-Industry and Forestry, Bruxelles, Belgio, December, pp 59-62

Capper JL, Cady RA (2012) A comparison of the environmental impact of Jersey compared with Holstein milk for cheese production. J Dairy Sci 95(1):165-176

Cederberg C, Mattsson B (2000) Life cycle assessment of milk production - a comparison of conventional and organic farming. J Cleaner Prod 8(1):49-60

Dalgaard R, Halberg N (2004) LCA of Danish milk-system expansion in practice. DIAS Report, An Hus 61:285-288

EarthShift (2012) US-EI Database. Available at http://www.earthshift.$\mathrm{com} /$ software/simapro/USEI-database. Accessed 28 September 2012

Energy Information Administration (EIA) (2003) Commercial buildings energy consumption survey. US Energy Information Administration. Available at http://www.eia.gov/emeu/cbecs/cbecs2003/detailed tables_2003/detailed tables_2003.html\#enduse03

Energy Information Administration (EIA) (2005) Residential Energy Consumption Survey (RECS), Consumption \& expenditures, home appliances and lighting. Available at http://www.eia.gov/ consumption/residential/data/2005/index.cfm\#tabs-2. Accessed 19 June 2011

Eide HM (2002) Life cycle assessment (LCA) of industrial milk production. Int J Life Cycle Assess 7(2):115-126

Energy Star (2008) Building upgrade manual chapter 11: grocery and convenience stores. Available at http://www.energystar.gov/ia/ business/EPA_BUM_Full.pdf

Energy Star (2009) Dishwashers key product criteria. Available at http://www.energystar.gov/index.cfm?c=dishwash.pr_crit_ dishwashers

Feitz AJ, Lundie S, Dennien G, Morain M, Jones M (2007) Generation of an industry-specific physico-chemical allocation matrix.
Application in the dairy industry and implications for systems analysis. Int J Life Cycle Assess 12(2):109-117

Food Marketing Institute (2010) Supermarket facts. Available at http:/ www.fmi.org/facts_figs/?fuseaction=superfact. Accessed 20 June 2011

Franklin Associates (2008) LCI summary for four half-gallon milk containers. Peer Reviewed Final Report, September 2008

Frischknecht R, Rebitzer G (2005) The ecoinvent database system: a comprehensive web-based LCA database. J Cleaner Prod 13(1314):1337-1343

Gerber P, Vellinga T, Opoio C, Henderson B, Steinfield H (2010) Greenhouse gas emissions from the dairy sector: a life cycle assessment. A report of the Food and Agriculture Organization, 96 pp. Available at http://www.fao.org/docrep/012/k7930e/k7930e00.pdf. Accessed 13 September 2012

Goedkoop M, Heijungs R, Huijbregts M, Schryver AD, Struijs J, Jelm R (2009) ReCiPe 2008. A life cycle impact assessment method which comprises harmonized category indicators at the midpoint and the endpoint level. Available at http://www.lcia-recipe.net

Haas G, Wetterich F, Kopke U (2001) Comparing intensive, extensified and organic grassland farming in southern Germany by process life cycle assessment. Agri Ecosys Environ 83:43-53

Hertwich EG, Pease WS, McKone TE (1998) Evaluating toxic impact assessment methods: what works best? Environ Sci Tech 32: A138-A144

Hischier R, Weidema B (2010) Implementation of life cycle impact assessment methods, data v2.2. Ecoinvent Center, Swiss Centre for Life Cycle Inventories. Available at http://www.ecoinvent.org/ fileadmin/documents/en/03_LCIA-Implementation-v2.2.pdf

Hospido A, Moreira MT, Feijoo G (2003) Simplified life cycle assessment of Galician milk production. Int Dairy J 13(10):783-796

Huijbregts MAJ, Thissen U, Guinee JB, Jager T, Van de Meent D, Ragas AMJ, Wegener SA, Reijnders L (2000) Priority assessment of toxic substances in life cycle assessment, I: calculation of toxicity potential for 181 substances with the nested multi-media fate, exposure and effects model USES-LCA. Chemosphere 41:541-573

IAC (2009) Industrial Assessment Centers Database. US Department of Energy, Washington, DC

IDFA (2010) Dairy facts. International Dairy Foods Association, Washington, DC

ISO (2006a) ISO 14040: environmental management-life cycle assessment-principles and framework. International Organization of Standardization, Geneva

ISO (2006b) ISO 14044: environmental management—-life cycle assessment-requirements and guidelines. International Organization of Standardization, Geneva

Jolliet O, Margni M, Charles R, Humbert S, Payet J, Rebitzer G, Rosenbaum R (2003) IMPACT 2002+: a new life cycle impact assessment methodology. Int $\mathrm{J}$ Life Cycle Assess 8 (6):324-330

Keoleian GA, Spitzley DV (1999) Guidance for improving life-cycle design and management of milk packaging. J Ind Ecol 3(1):111-126

Lautier A, Rosenbaum RK, Margni M, Bare J, Roy PO, Beschenes L (2010) Development of normalization factors for Canada and the United States and comparison with European factors. Sci Tot Env 409(1):33-42

Lundie S, Feitz A, Jones M, Dennien G, Morian M (2003) Evaluation of the environmental performance of the Australian dairy processing industry using life cycle assessment. Dairy Research and Development Corporation, Canberra

NASS (2010) National Agricultural Statistics Service, Wisconsin Agricultural Statistics, United States Department of Agriculture (USDA-NASS) in cooperation with Wisconsin Department of Agriculture, Trade and Consumer Protection (WDATCP), Washington, DC. Available at http://www.nass.usda.gov. Accessed 11 December 2011 
NADA (2011) National Automobile Dealers Association Data, State of the Industry Report, NADA's Industry Analysis Division. Available at http://www.nada.org/nadadata

NHTS (2009) Federal Highway Administration. National Household Travel Survey. Available at http://nhts.ornl.gov

Nielsen P, Høier E (2009) Environmental assessment of yield improvements obtained by the use of the enzyme phospholipase in mozzarella cheese production. Int J Life Cycle Assess 14(2):137-143

Nutter DW, Kim D, Ulrich R, Thoma G (2012) Greenhouse gas emission analysis for USA fluid milk processing plants: processing, packaging, and distribution. Int Dairy J. doi:10.1016/j.idairyj.2012.09.011

SimaPro@ 7.3, PRé Consultants, The Netherlands (2012) Available at http://www.pre.nl/

Sonesson U, Berlin J (2003) Environmental impact of future milk supply chains in Sweden: a scenario study. J Clean Prod 11:253-266

Thoma G, Popp J, Shonnard D, Nutter D, Matlock M, Ulrich R, Kellogg W, Kim DS, Neiderman Z, Kemper N, Adom F, East C (2012a) Regional analysis of greenhouse gas emissions from US dairy farms: a cradle to farm-gate assessment of the American dairy industry circa 2008. Int Dairy J. doi:10.1016/j.idairyj.2012.09.010
Thoma G, Popp J, Nutter D, Shonnard D, Ulrich R, Matlock M et al (2012b) Greenhouse gas emissions from milk production and consumption in the United States: a cradle to grave life cycle assessment circa 2008. Int Dairy J. doi:10.1016/j.idairyj.2012.08.013

TSC (2012) Open IO. The Sustainability Consortium. Available at http://www.sustainabilityconsortium.org/open-io/. Accessed 4 December 2012

US Census Bureau (2009) Available at http://www.census.gov/acs/ www/data documentation/2009 release/

USDA (2010) Economic Research Service. Loss-adjusted food availability. United States Department of Agriculture. Available at http://www. ers.usda.gov/Data/FoodConsumption/FoodGuideSpreadsheets.htm

van Middelaar CE, Berentsen PBM, Dolman MA, de Boer IJM (2011) Eco-efficiency in the production chain of Dutch semi-hard cheese. Livestock Sci 139(1-2):91-99

Williams AG, Audsley E, Sandars DL (2006) Determining the environmental burdens and resource use in the production of agricultural and horticultural commodities. Main report. Defra Research Project IS0205. Cranfield University and Defra, Bedford 